Jurnal Indonesia Sosial Teknologi: p-ISSN: 2723 - 6609

e-ISSN : 2745-5254

Vol. 2, No. 5 Mei 2021

\title{
PEMANFAATAN CITRA LANDSAT 8 UNTUK ESTIMASI LUAS LAHAN TERBANGUN DAN TIDAK TERBANGUN PADA KOTA BANDUNG
}

\section{Indra Permana Solihin dan Rachmad Kurniyanto}

Fakultas Ilmu Komputer Universitas Pembangunan Nasional Veteran Jakarta

Email: rachmadkurniyanto@gmail.com

\section{Abstract}

The current economic development and population growth in the city of Bandung is likely to result in an imbalance in land use. On the other hand, to meet the needs of the community, the role of the government is needed to pay attention to continuous urban planning so that the quality of life of the community is maintained and there is a balance between the natural and the artificial environment. So we need a system that is able to monitor the development of land use by utilizing the Geographical Information System analysis. This study uses the NDBI (transformation Normalized Difference Built-Up Index) to detect built-up land in the city of Bandung. The rate of development that occurred in the built-up land in the city of Bandung increased in 2017 to 2019 from $79.14 \mathrm{Km}^{2}$ to $88.03 \mathrm{Km}^{2}$, the development is about $4 \mathrm{Km}^{2}$ per year. Unawakened land in the city of Bandung detected by landsat image in 2015 amounting to $89.23 \mathrm{Km}^{2}$, in 2016 amounted to $92.60 \mathrm{Km}^{2}$, in $201789.15 \mathrm{Km}^{2}$, in $201883.77 \mathrm{Km}^{2}$, in $201980.24 \mathrm{Km}^{2}$. There were constraints in the 2016 study, the amount of land area built and not awakened experienced a difference compared to other years, caused by the cover of landsat image by clouds or cloud shadows.

Keyword: development; built-up land; NDBI (normalized difference built-Up index).

\begin{abstract}
Abstrak
Perkembangan ekonomi dan pertumbuhan penduduk di kota Bandung yang sangat pesat saat ini, dimungkinkan akan mengakibatkan ketidakseimbangan pada penggunaan lahan. Dari sisi lain untuk memenuhi kebutuhan masyarakat, diperlukan peran pemerintah untuk memperhatikan tata kota yang berkelanjutan agar kualitas hidup masyarakat tetap terjaga dan ada keseimbangan antara lingkungan alami dan buatan. Maka dibutuhkan sistem yang mampu memonitoring perkembangan penggunaan lahan dengan memanfaatkan analisis Sistem Informasi Geografis. Penelitian ini menggunakan transformasi NDBI (Normalized Difference Built-Up Index) untuk mendeteksi lahan terbangun yang ada di kota Bandung. Tingkat perkembangan yang terjadi pada lahan terbangun di kota Bandung mengalami peningkatan pada tahun 2017 sampai tahun 2019 dari 79,14 Km² menjadi $88,03 \mathrm{Km}^{2}$, perkembangannya sekitar $4 \mathrm{Km}^{2}$ pertahun. Lahan tidak terbangun pada kota Bandung yang terdeteksi oleh citra landsat pada tahun 2015 sebesar 89,23 $\mathrm{Km}^{2}$, tahun 2016 sebesar 92,60 Km², tahun $201789,15 \mathrm{Km}^{2}$, tahun 2018 83,77 Km², tahun 2019 80,24 Km². Ditemukan kendala pada penilitian tahun 2016, jumlah luas lahan terbangun dan tidak terbangun mengalami perbedaan
\end{abstract}


dibandingkan dengan tahun tahun yang lainnya, disebabkan oleh tertutupnya citra landsat oleh awan atau bayangan awan.

Kata kunci: perkembangan; lahan terbangun; NDBI (normalized difference built-Up index).

\section{Pendahuluan}

Kota Bandung merupakan Ibukota Jawa Barat dan menjadi salah satu kota besar di Indonesia dan merupakan pusat pemerintahan pada provinsi Jawa Barat. Luas wilayah kota Bandung pada tahun 2017 seluas $167.31 \mathrm{Km}^{2}$, dan mempunyai 30 Kecamatan dan 151 Kelurahan, sehingga Kota Bandung merupakan salah satu kota terpadat di Jawa Barat.

Dalam perkembangannya, gejala perubahan pemanfaatan lahan, justru menjadi gejala alamiah dalam suatu evolusi Provinsi (Wikantika \& Agus, 2006). Bentuk perubahan ini tidak terjadi di setiap lokasi secara seragam, karena setiap lahan memiliki tingkat kestrategisan dan potensi yang berbeda. Pengalokasian guna lahan di per Provinsian akan mengarah kelokasi yang dapat memberikan keuntungan tertinggi (Goldberg dalam Yunus, 2000), Penelitian ini menggunakan citra Landsat sebagai data utama dalam pengujian dan metode NDBI untuk mengetahui kondisi lahan terbangun maupun tidak terbangun secara cepat dan akurat, dan teknologi Sistem Informasi Geografis (SIG) (Lucyana, 2016). Citra Landsat didapat dari website USGS (United State Geological Survey) yang beralamat https:/learthexplorer.usgs.gov/ (Sampurno \& Thoriq, 2016).

Berdasakan hal tersebut, dalam memperoleh data kawasan lahan terbangun maupun tidak terbangun penulis akan mengunakan metode Normalized Difference Built-Up Index (NDBI) dalam penelitiannya. Pengambilan citra dilakukan berdasarkan path 122 row 65 dan tanggal daerah kota Bandung. Citra landsat yang dibutuhkan yaitu Band 5 dan Band 6 pada tahun 2015, 2016, 2017, 2018 dan 2019 (LANDSAT, 2014).

\section{Metode Penelitian}

Menerangkan tentang Sistem Informasi Geografis (SIG) berfungsi sebagai proses dalam mengolah landsat di antaranya operator clipyang berfungsi memotong band landsat 8 dengan polygon Bandung sehingga membentuk sebuah layer baru berupa band dengan cakupan area terbatas pada wilayah Bandung (Sitanggang, 2010).

\section{Normal Difference Build-up Index (NDBI)}

Metode deteksi wilayah permukiman ini dilakukan secara digital dengan mempergunakan variabel indeks lahan terbangun (Normalized Difference Build-up Index) atau disingkat dengan NDBI. NDBI diperkenalkan oleh Zha et al. (2003) untuk otomatisasi proses pemetaan lahan terbangun. Pada penelitian tersebut ditemukan bahwa pola spektral daerah perkotaan berbeda dengan tutupan lahan lainnya. Daerah 
perkotaan sangat sensitif terhadap band NIR (Near-Infrared) dan band SWIR 1 (Short Wave Infrared) (Mahardika, 2020).

Berikut merupakan rumus metode NDBI.

$$
N D B I=\frac{b 6-b 5}{b 6+b 5}=\frac{S W I R 1-N I R}{S W I R 1+N I R}
$$

\section{Hasil dan Pembahasan}

Dari penelitian pemanfaatan citra landsat 8 untuk estimasi luas lahan terbangun dan tidak terbangun pada kota Bandung ini, merupakan suatu yang terdiri dari beberapa proses untuk sehingga dari input yang diproses dapat memberikan output yang dibutuhkan (SASMITO et al., 2018).

\section{Prepocessing}

Pada tahap ini citra landsat melalui beberapa proses untuk mempersiapkan data dalam proses pengujian (Frananda \& Chandra, 2018). Proses prepocessing ini meliputi copy raster, cliping dan raster calculator.

\section{Copy raster}

Proses copy raster menggunakan tool copy raster pada aplikasi ArcGIS berfungsi untuk pembersihan pada citra landsat dari yang tidak dibutuhk.
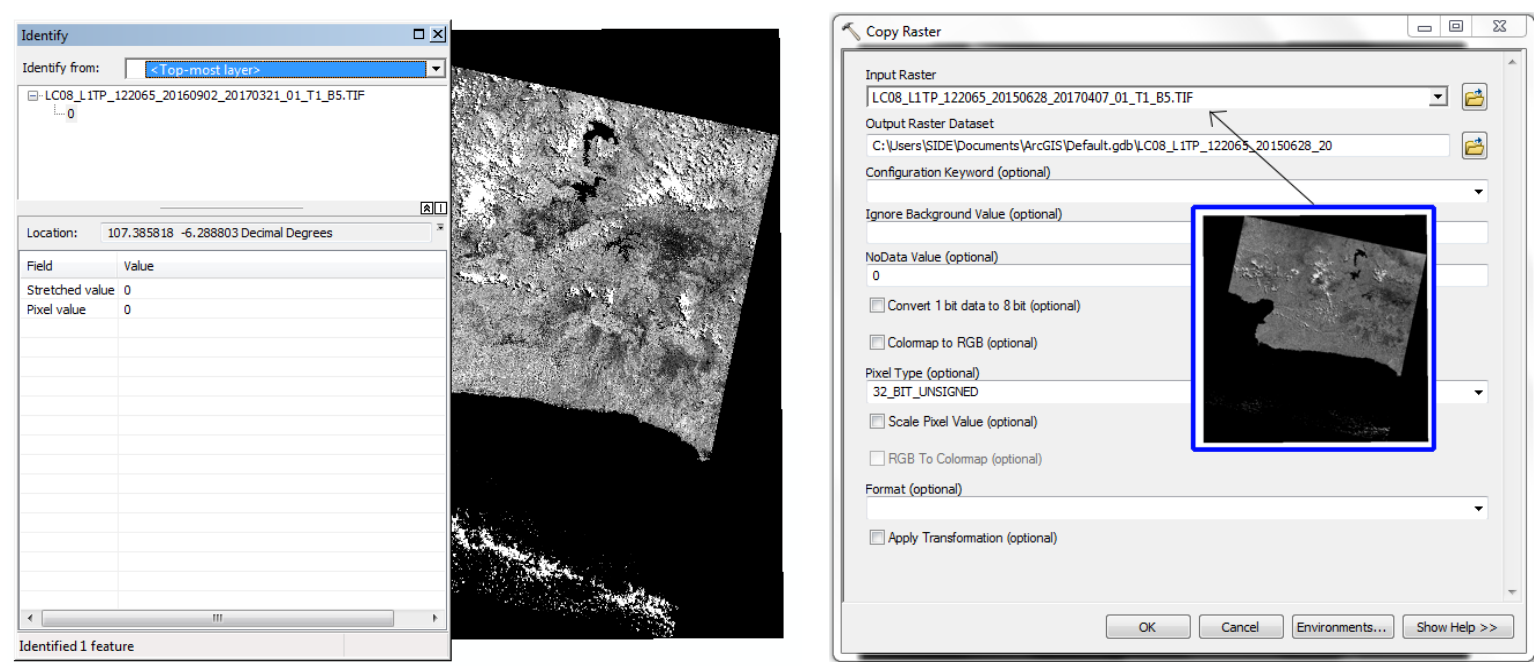

Gambar. 1. Proses copy raster dengan menggunakan tool copy raster.

Pada Input Raster dipilih Band yang ingin diproses, dan pada Output Raster Dataset diisi nama file hasil dari proses copy raster (Umum \& DATA, 2013). Selanjutnya pada form NoData Value diisi 0. Setelah melalui proses dengan menggunakan tool copy raster didapatkan hasil seperti digambar 


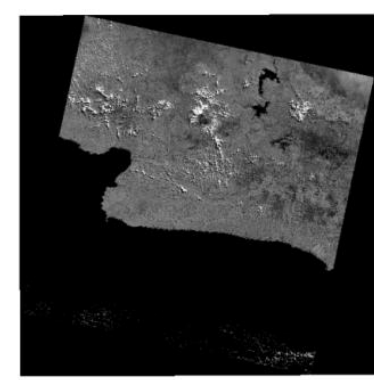

Band 5 Sebelum Copy raster

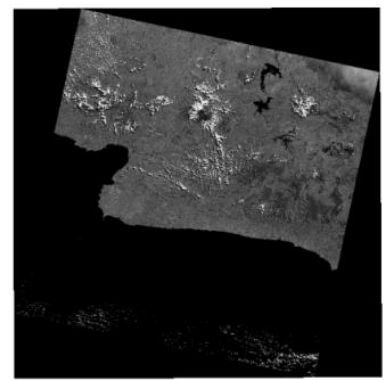

Band 6 Sebelum Copy raster

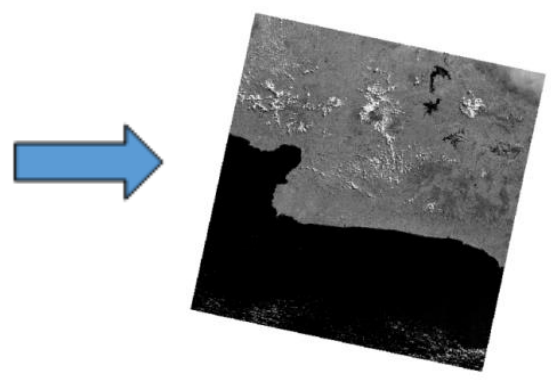

Band 5 Sesudah Copy raster

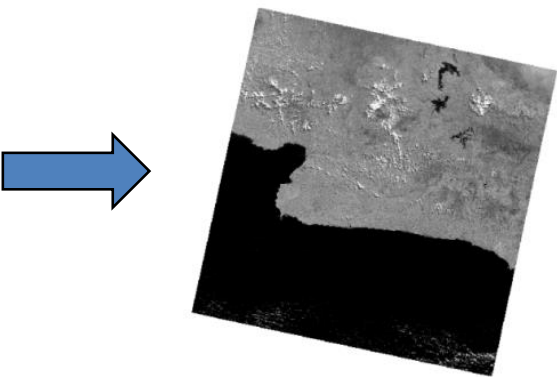

Band 6 Sesudah Copy raster

Gambar. 2. Hasil proses copy raster pada band 5 dan 6.

\section{Clip}

Pada prosesini citra landsat yang sudah melalui proses copy raster selanjutnya di clipping sesuai dengan shapefile kota Bandung (Kurniawan et al., 2020) untukmemotong citra sesuai dengan batas batas kota bandung dan menjadi data yang dibutuhkan untuk penelitian. Gambar berikut ini adalah shapefile kota Bandung.

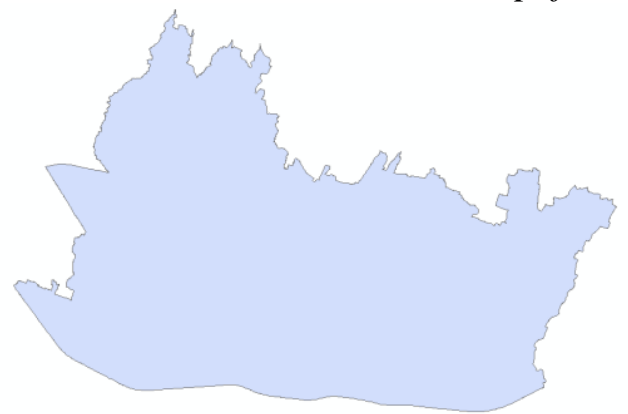

\section{Gambar. 3. Shapefile Kota Bandung}

Proses clipping pada proses ini menggunakan tools clip pada aplikasi Arcgis 10.3. Parameter input pada proses clipping yaitu citra landsat sebagai citra yang akan dipotong dan Shapefile Kota sebagai pemotong citra landsat. Dilakukannya proses clipping untuk mendapatkan citra landsat hanya Kota Bandung.

Untuk mencarinya tool tersebut ada pada (Data Management) (Tool) selanjutnya Clip. Berikut merupakan langkah proses clipping. 


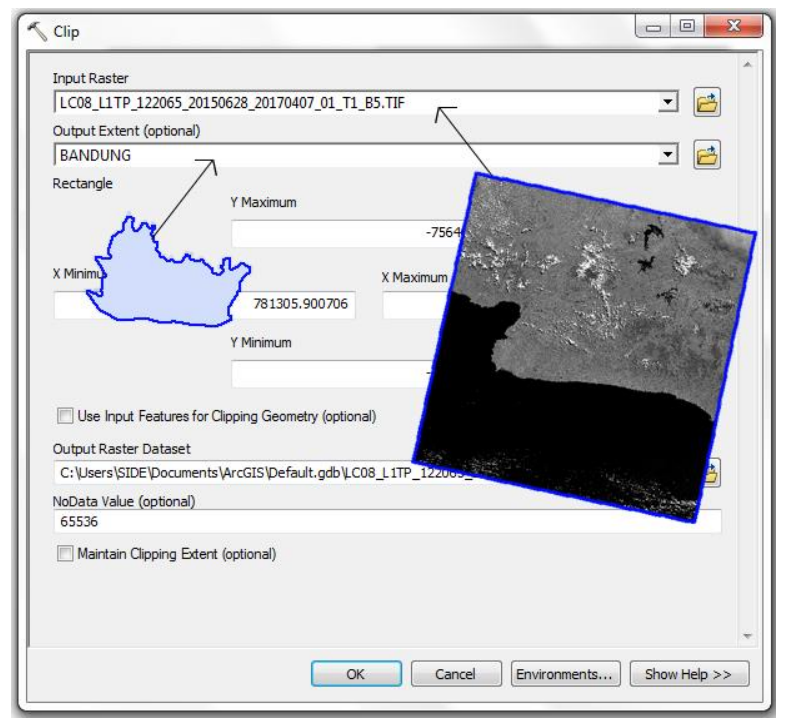

Gambar. 4. Proses clipping

Pada form Input Raster masukkan citra hasil copy raster yang ingin di clipping. Pada form Output Extent masukkan shapefile Kota Bandung sebagai pemotong citra terbesebut.

Citra landsat yang akan di clip yaitu Band 5 dan Band 6 pada tahun 2015, 2016, 2017, 2018 dan 2019. Setelah melalui proses dengan menggunakan tool copy raster didapatkan hasil seperti digambar

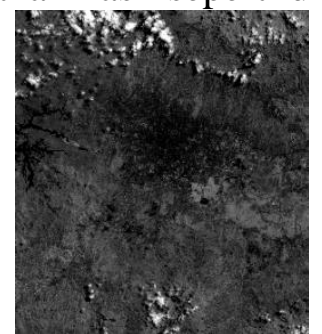

Band 5 Sebelum Clipping

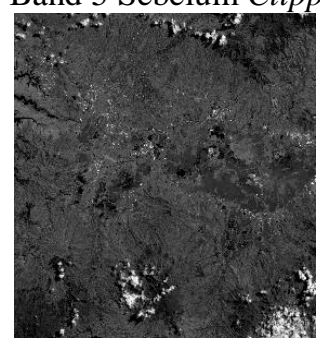

Band 6 Sebelum Clipping

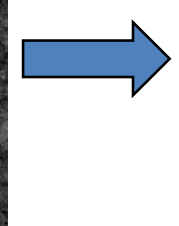

\section{(8)}

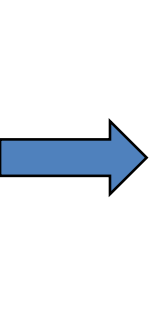

\section{Gambar. 5. Hasil proses clipping}

\section{Proses Transformasi}

Setelah citra landsat melalui proses cliping tahap selanjutnya yaitu transformasi dengan menggunakan metode NDBI (Amalia, 2017). Pada metode ini NDBI akan membagi menjadi 2 class dan memiliki aturan yang sudah ditetapkan yaitu pola yang dihasilkan nilai negatif untuk daerah perairan atau pertanian / perhutanan dan nilai positif untuk lahan terbangun, perhitungannya menggunakan rumus dibawah ini. 


$$
N D B I=\frac{b 6-b 5}{b 6+b 5}=\frac{S W I R 1-N I R}{S W I R 1+N I R}
$$

Keterangan : SWIR1 merupakan Band 6 dan NIR merupakan B5

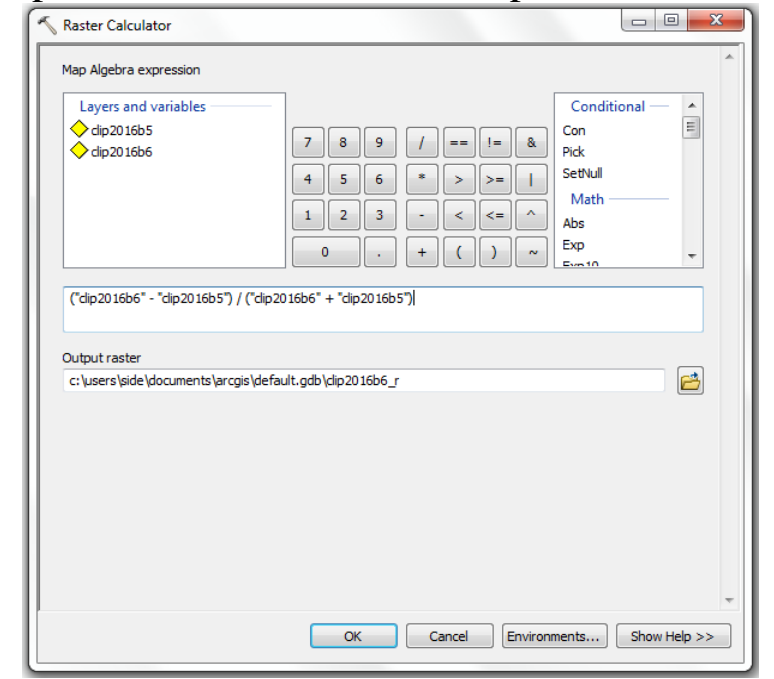

Gambar. 6. Proses penggunaan rumus NDBI pada tool Raster Calculator.

Penerapan rumus NDBI: clip2016b5 merupakan Band 5, clip2016b6 merupakan Band 6. ("clip2016b6"-"clip2016b5") / ("clip2016b6"+" clip2016b5").

Pada hasil metode NDBI ini didapatkan nilai dari lahan terbangun dan lahan tidak terbangun, dan tentang nilai NDBI adalah.

Tabel 1. Rentang Nilai NDBI

\begin{tabular}{cc}
\hline Rentang Nilai NDBI value & Kelas \\
\hline$-1 \mathrm{~s} / \mathrm{d} 0$ & Tidak Terbangun \\
\hline $0 \mathrm{~s} / \mathrm{d} 1$ & Terbangun \\
\hline
\end{tabular}

Tahap selanjutnya adalah pengujian metode pada kedua Band 5 dan Band 6 dimasing-masing tahun agar penulis mendapatkan informasi data lahan terbangun dan tidak terbangun pada Kota Bandung.

1. Pengujian pada tahun 2015

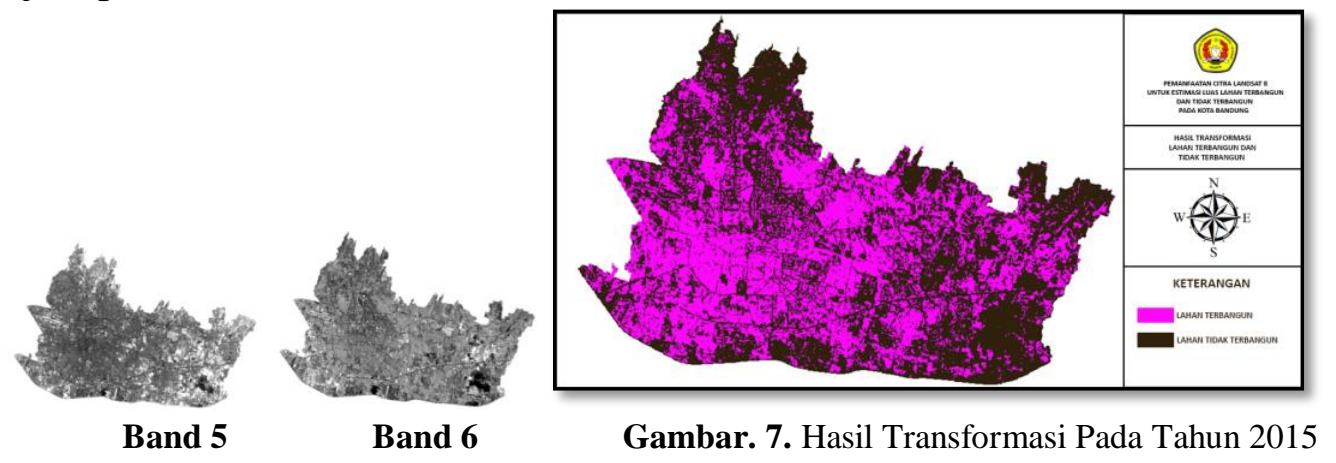


Berdasarkan hasil pengujian diatas. Didapatkan nilai dari lahan terbangun dan tidak terbangun pada tahun 2015. Berikut adalah hasil pengujian tersebut.

Tabel 2. Hasil pengujian nilai NDBI tahun 2015

\begin{tabular}{ccc}
\hline Rentang Nilai NDBI value & Kelas & Jumlah Pixel \\
\hline 0 & Lahan Terbangun & 87832 \\
\hline-1 & Tidak Terbangun & 99148 \\
\hline
\end{tabular}

2. Pengujian pada tahun 2016

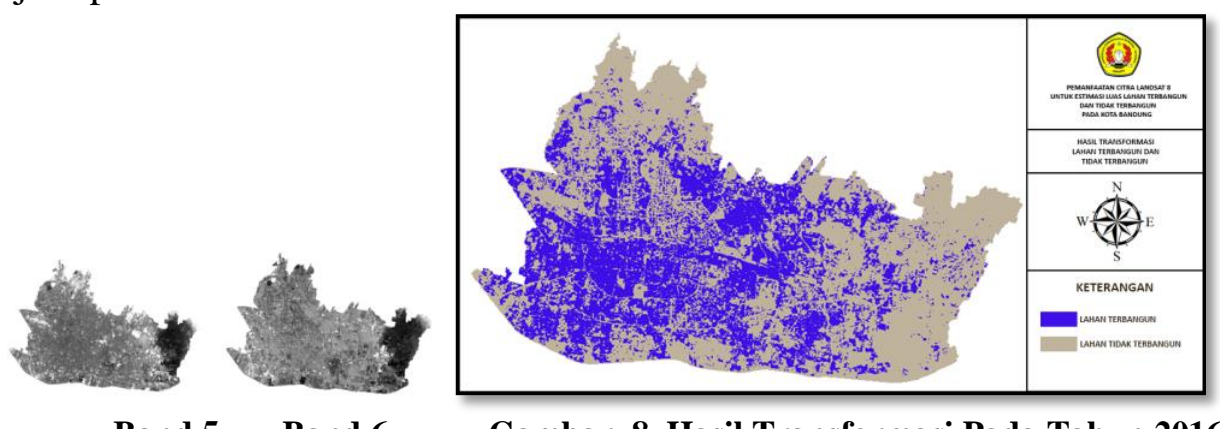

Band 5 Band 6

Gambar. 8. Hasil Transformasi Pada Tahun 2016

Berdasarkan hasil pengujian diatas didapatkan nilai dari lahan terbangun dan tidak terbangun pada tahun 2016. Berikut adalah hasil pengujian tersebut.

Tabel 3. Hasil pengujian nilai NDBI tahun 2016

\begin{tabular}{ccc}
\hline Rentang Nilai NDBI value & Kelas & Jumlah Pixel \\
\hline 0 & Lahan Terbangun & 84091 \\
\hline-1 & Tidak Terbangun & 102889 \\
\hline
\end{tabular}

3. Pengujian pada tahun 2017

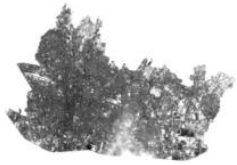

Band 5

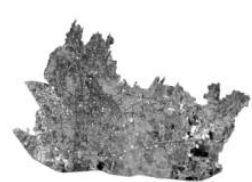

Band 6

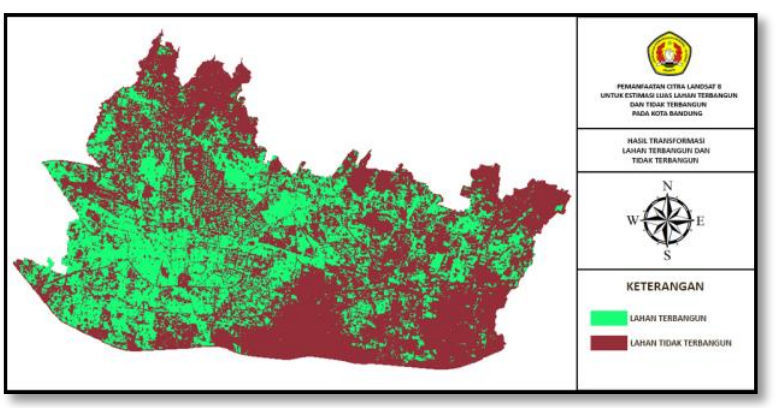

Gambar. 9. Hasil Transformasi Pada Tahun 2017

Berdasarkan hasil pengujian diatas didapatkan nilai dari lahan terbangun dan tidak terbangun pada tahun 2017. Berikut adalah hasil pengujian tersebut.

Tabel 4. Hasil pengujian nilai NDBI tahun 2017

\begin{tabular}{ccc}
\hline Rentang Nilai NDBI value & Kelas & Jumlah Pixel \\
\hline 0 & Lahan Terbangun & 87924 \\
\hline-1 & Tidak Terbangun & 99056 \\
\hline
\end{tabular}


4. Pengujiuan pada tahun 2018

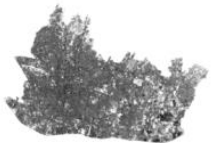

Band 5

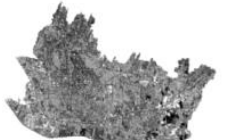

Band 6

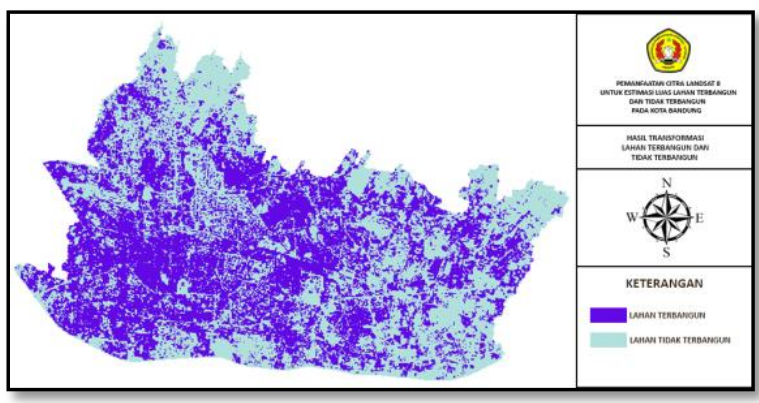

Gambar. 10. Hasil Transformasi Pada Tahun 2018

Berdasarkan hasil pengujian diatas didapatkan nilai dari lahan terbangun dan tidak terbangun pada tahun 2018. Berikut adalah hasil pengujian tersebut.

Tabel 5. Hasil pengujian nilai NDBI tahun2018

\begin{tabular}{ccc}
\hline Rentang Nilai NDBI value & Kelas & Jumlah Pixel \\
\hline 0 & Lahan Terbangun & 93893 \\
\hline-1 & Tidak Terbangun & 93087 \\
\hline
\end{tabular}

5. Pengujian pada tahun 2019

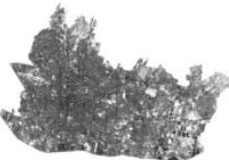

Band 5

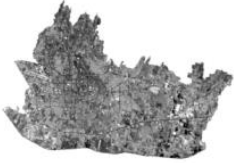

Band 6

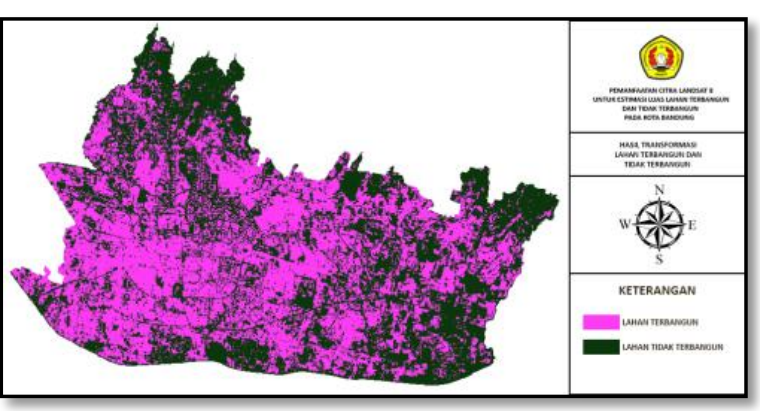

Gambar. 11. Hasil Transformasi Pada Tahun 2019

Berdasarkan hasil pengujian diatas didapatkan nilai dari lahan terbangun dan tidak terbangun pada tahun 2019. Berikut adalah hasil pengujian tersebut.

Tabel 6. Hasil pengujian nilai NDBI tahun 2019

\begin{tabular}{ccc}
\hline Rentang Nilai NDBI value & Kelas & Jumlah Pixel \\
\hline 0 & Lahan Terbangun & 97821 \\
\hline-1 & Tidak Terbangun & 89159 \\
\hline
\end{tabular}

Untuk menghitung ke ukuran sebenarnya, terlebih dahulu luas pada hasil pengujian dikalikan 900, dikarenakan 1 pixel pada citra sama dengan dengan ukuran 30 $\mathrm{m} \times 30 \mathrm{~m}$ di ukuran sebenarna, maka dapat disimpulkan bahwa 1 pixel sama dengen 
Indra Permana Solihin dan Rachmad Kurniyanto

$900 \mathrm{~m}^{2}$. Hasilnya masih dalam satuan meter persegi, kemudian diubah ke dalam satuan kilometer persegi, yaitu dengan dibagi 1.000.000 (Rivaldi, 2018).

Berikut adalah hasil pengujian Luas Lahan Terbangun.

Tabel 7. Luas Lahan Terbangun

\begin{tabular}{ccc}
\hline Tahun & Lahan Terbangun (Pixel) & Luas Km$^{2}$ \\
\hline 2015 & 87832 & $87832 \times 900 \div 1.000 .000=79,04 \mathrm{Km}^{2}$ \\
\hline 2016 & 84091 & $84091 \times 900 \div 1.000 .000=75,68 \mathrm{Km}^{2}$ \\
\hline 2017 & 87924 & $87924 \times 900 \div 1.000 .000=79,13 \mathrm{Km}^{2}$ \\
\hline 2018 & 93893 & $93893 \times 900 \div 1.000 .000=84,5 \mathrm{Km}^{2}$ \\
\hline 2019 & 97821 & $97821 \times 900 \div 1.000 .000=88,03 \mathrm{Km}^{2}$ \\
\hline
\end{tabular}

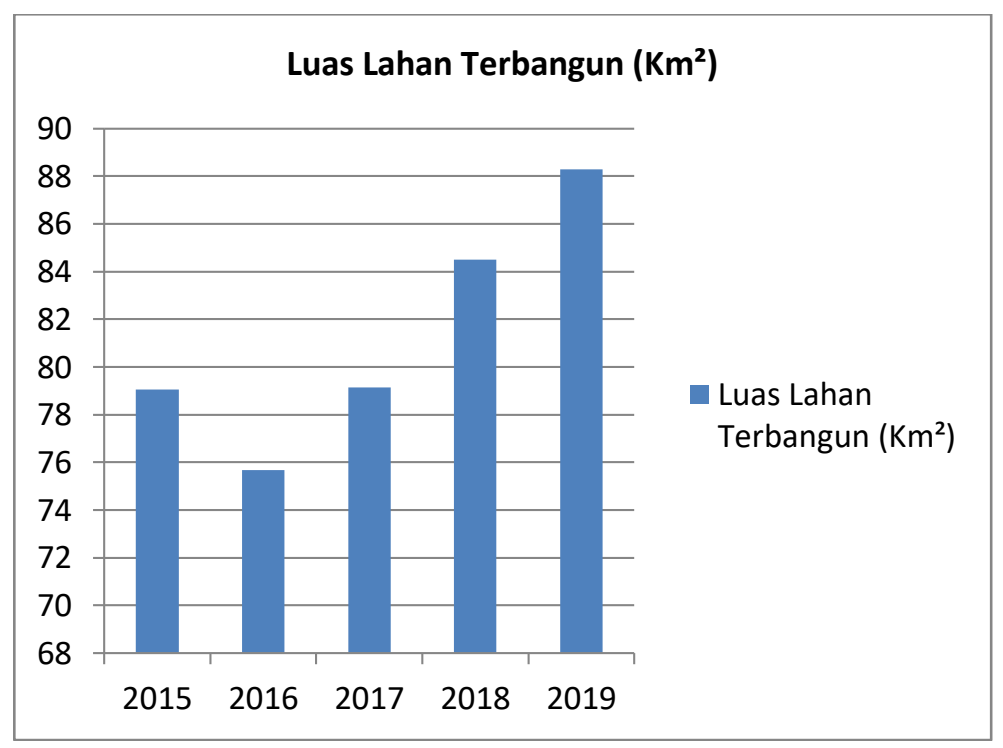

Gambar. 12. Diagram Luas Lahan Terbangun

Berikut adalah hasil pengujian Luas Lahan Tidak Terbangun.

Tabel 8. Luas Lahan Tidak Terbangun

\begin{tabular}{ccc}
\hline Tahun & Lahan Tidak Terbangun (Pixel) & Luas Km $^{2}$ \\
\hline 2015 & 99148 & $99148 \times 900 \div 1.000 .000=89,23 \mathrm{Km}^{2}$ \\
\hline 2016 & 102889 & $102889 \times 900 \div 1.000 .000=92,60 \mathrm{Km}^{2}$ \\
\hline 2017 & 99056 & $99056 \times 900 \div 1.000 .000=89,15 \mathrm{Km}^{2}$ \\
\hline 2018 & 93087 & $93087 \times 900 \div 1.000 .000=83,77 \mathrm{Km}^{2}$ \\
\hline 2019 & 89159 & $89159 \times 900 \div 1.000 .000=80,24 \mathrm{Km}^{2}$ \\
\hline
\end{tabular}




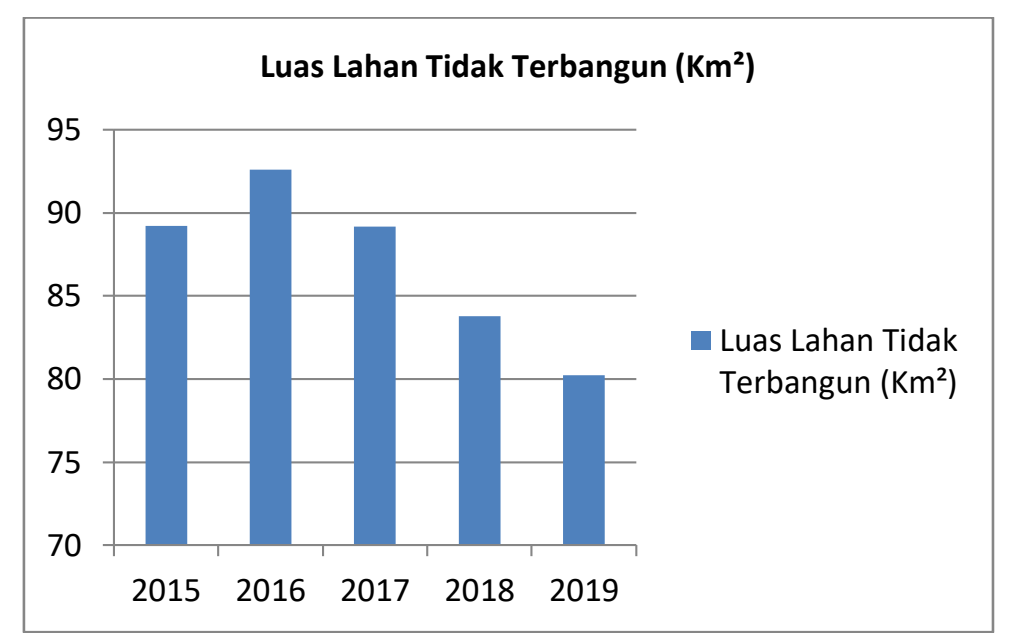

Gambar. 13. Diagram Luas Lahan Tidak Terbangun

Berdasarkan hasil penelitian ini diperoleh perkembangan perubahan lahan terbangun maupun tidak terbangun pada Kota Bandung pada rentang waktu dari Tahun 2015 sampai Tahun 2019.

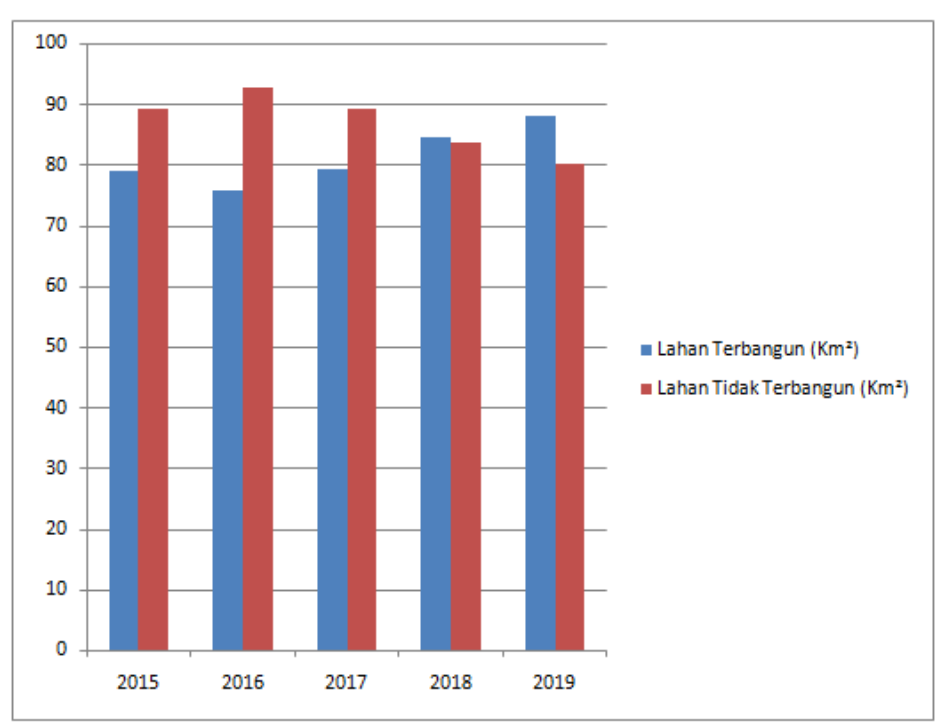

Gambar. 14. Diagram Hasil Penelitian

Dari hasil pengujian ini, dapat diketahui bahwa kualitas citra landsat sangat berpengaruh dalam hasil pengujian. Jika diperhatikan hasil pengujian pada tahun 2016 terdapat selisih terbalik nilai dari tahun-tahun yang lain, dikarenakan citra landsat pada tahun 2016 terdapat awan yang menutupi sebagian citra landsat.Setelah pengujian ini dapat disimpulkan kota Bandung mengalami perkembangan pembangunan yang pada tahun 2017, 2018 dan 2019 sekitar $4 \mathrm{Km}^{2}$ disetiap tahunnya

\section{Kesimpulan}


Lahan terabangun pada kota Bandung yang terdeteksi oleh citra landsat pada tahun 2015 sebesar 79,04 Km², tahun 2016 sebesar 75,68 Km², tahun 2017 79,13 Km², tahun 2018 84,5 Km², tahun 2019 88,03 Km². Tingkat perkembangan yang terjadi pada lahan terbangun di kota Bandung mengalami peningkatan pada tahun 2017 sampai tahun 2019 dari 79,14 $\mathrm{Km}^{2}$ menjadi 88,03 $\mathrm{Km}^{2}$, perkembangannya sekitar $4 \mathrm{Km}^{2}$ pertahun. Lahan tidak terbangun pada kota Bandung yang terdeteksi oleh citra landsat pada tahun 2015 sebesar 89,23 $\mathrm{Km}^{2}$, tahun 2016 sebesar 92,60 $\mathrm{Km}^{2}$, tahun 201789,15 $\mathrm{Km}^{2}$, tahun 2018 83,77 Km², tahun 2019 80,24 Km².

Jumlah luas pada lahan tidak terbangun dari tahun 2015 sampai dengan tahun 2019 mengalami penurunan, yang diakibatkan meningkatnya pembangunan yang terjadi dari 99148 pixel atau 89,23 $\mathrm{Km}^{2}$ menjadi 89159 pixel 80,24 $\mathrm{Km}^{2}$. Ditemukan kendala pada penilitian tahun 2016, jumlah luas lahan terbangun dan tidak terbangun mengalami perbedaan dibandingkan dengan tahun tahun yang lainnya, disebabkan oleh tertutupnya citra landsat oleh awan atau bayangan awan.

\section{Bibliography}

Amalia, S. (2017). Analisis Hubungan Produksi Padi Dengan Nilai Ndvi (Normalized 
Difference Vegetation Index) Menggunakan Citra Landsat 8 Di Kecamatan Ingin Jaya. ETD Unsyiah.

Frananda, H., \& Chandra, D. (2018). Pemanfaatan Citra Landsat 8 Untuk Pemetaan Ekosistem Mangrove Di Kota Padang. Jurnal Geografi Vol, 7(1), 104.

Kurniawan, D. E., Kom, M., Afdhol Dzikri, M. T., Irawan, S., \& Oktavianto Gustin, M. T. (2020). Sistem Informasi Geografis: Praktikum Dan Penerapan Dalam Pengambilan Keputusan. PolibatamPress.

LANDSAT, V. M. C. (2014). Deteksi Wilayah Permukiman Pada Bentuklahan Vulkanik Menggunakan Citra Landsat-8 Oli Berdasarkan Parameter Normalized Difference Build-Up Index (NDBI). Seminar Nasional Penginderaan Jauh, 345.

Lucyana, R. (2016). Sistem Informasi Geografis untuk pemetaan pariwisata kabupaten pesisir barat berbasis web.

Mahardika, A. 202. (2020). "Riset UNPAD: Terdampak Corona, 47\% Mahasiswa Alami Gejala Depresif." $\quad$ Detik.Com. Detik.com/health/beritadetikhelath/d4980296/riset-unpad-terdampak-corona-47-persen-mahasiwa-alamigejala-depresif.

S, R. (2018). Pemanfaatan Citra Landsat 8 Untuk Estimasi Luas Lahan Sawah Dengan Klasifikasi Tidak Terbimbing.

Sampurno, R. M., \& Thoriq, A. (2016). Klasifikasi tutupan lahan menggunakan citra landsat 8 operational land imager (OLI) di Kabupaten Sumedang (land cover classification using landsat 8 operational land imager (OLI) data in Sumedang Regency). Jurnal Teknotan Vol, 10(2).

SASMITO, B., Hani'ah, H., \& Suprayogi, A. (2018). Pemanfaatan Enhanced Built-Up And Bareness Index (Ebbi) Untuk Pemetaan Kawasan Terbangun Dan Lahan Kosong Di Kota Semarang. Universitas Diponegoro.

Sitanggang, G. (2010). Kajian pemanfaatan satelit masa depan: sistem penginderaan jauh satelit LDCM (LANDSAT-8). Berita Dirgantara, 11(2).

Umum, K. P., \& DATA, P. P. (2013). Dasar-Dasar Sistem Informasi Geografis (SIG). Jakarta: Pusdata.

Wikantika, K., \& Agus, A. (2006). Analisis Perubahan Luas Pertanian Lahan Kering Menggunakan Transformasi Tasseled Cap (Studi Kasus: Kawasan Puncak-Jawa Barat). Jurnal Infrastruktur Dan Lingkungan Binaan, 2(1). 